\title{
Medieval Studies in Australia: Some Thoughts on 'Relevance'
}

\author{
Andrew Lynch
}

Medieval studies in Australia face challenges from both outside and within the academy. One of them may come from a decline in university enrolments in the humanities areas where medieval content most often features; that seems still uncertain in Australia, though evident in the USA. ${ }^{1}$ Another is the increasing trend towards radical futurology in Australian public discourse on universities: 'Nearly half of degrees soon to be worthless, leaving students with "more debt and poor job prospects", says one News Corp site, adding "The courses that scored poorly in job relevance were humanities, culture and social sciences with just 36 per cent'. ${ }^{2}$ Such views are convincingly refuted by the HASS sector, ${ }^{3}$ but Australian Government actions reveal a narrower notion of employment relevance and 'national benefit' ${ }^{4}$ University administrations are also embracing the view that research means collaboration with business and industry to 'help solve not only today's problems, but those of the future'. ${ }^{5}$ With that, they are putting heavy emphasis on using technological media, both in research and to streamline and diversify undergraduate teaching and learning. In the absence of a similar emphasis on curriculum content, it sometimes seems that technology itself has become the main game, and the perceived value of the humanities will depend on the extent to which they adopt it.

$1 \quad$ See Glenn Withers, 'An Australian Humanities Crisis?', in The Changing Face of Higher Education: Is There an International Crisis in the Humanities?, ed. by Dennis A. Ahlberg (Abingdon: Routledge, 2019); Corydon Ireland, 'Mapping the Future', Harvard Gazette, 6 June $2013<\mathrm{https}$ //news.harvard.edu/gazette/story/2013/06/mapping-the-future/>; Benjamin Schmidt, 'The Humanities Are in Crisis'. The Atlantic, 23 August $2018<$ https://www.theatlantic.com/ ideas/archive/2018/08/the-humanities-face-a-crisisof-confidence/567565/>.

2 Frank Chung, 'Nearly Half of Degrees Soon to Be Worthless, Leaving Students with "more debt and poor job prospects", news.com.au, 2 May 2018. <https://www.news.com.au/ finance/work/careers/nearly-half-of-degrees-soon-to-be-worthless-leaving-students-with-moredebt-and-poor-job-prospects/news-story/983dce074b81ac1402b66433115d4e97>.

3 See Australasian Council of Deans of Arts, Humanities and Social Sciences, 'Humanities, Arts and Social Sciences Degrees', DASSH_HASS_and_Future_Workforce_ FINAL_Report_2018.11_.19_.

4 Michael Koziol, 'Former Education Minister Vetoed \$4.2 Million in Recommended University Research Grants', Sydney Morning Herald, 26 October $2018<$ https://www.smh.com. $\mathrm{au} /$ politics/federal/former-education-minister-vetoed-4-2-million-in-recommended-universityresearch-grants-20181026-p50c3a.html>.

5 See UWA Research Institutes and Centres $<$ https://www.research.uwa.edu.au/list-ofcentres> [accessed 30 June 2019]. 
Australian scholars and teachers of the medieval, and of other areas which look far off in time, region, language, or culture from 'today's problems', are getting used to living in this environment, and have been very resourceful in adapting to it. They need to be. Yet there is a danger for medieval studies, in particular, in having to fight on this ground. The assumptions empowering economically and technologically driven notions of 'relevance', 'today's problems', and 'the future' intersect with a long cultural memory that casts the 'medieval' as a superseded era no longer connected with our world, and in particular as laughably deficient in innovation and technology. Today's generation of senior administrators are likely to have been weaned on the 'Disney Classic', 'flat earth' Middle Ages of The Sword in the Stone, where Merlin tells the young Arthur 'First of all, lad, we've got to get all these medieval ideas out of your head, clear the way for new ideas, knowledge of man's fabulous discoveries in the centuries ahead', meaning here the steam engine, the industrial production line, and heavier-than-air flight. ${ }^{6}$ Medieval and medievalist scholars rightly contest the notion of medieval technological incapability, but although that can readily be done, similar technological versions of 'new ideas' and future 'fabulous discoveries' are being used to evaluate the potential research contribution of the humanities. So, while we investigate new methodologies, and continue to collaborate across disciplines, we should also be contesting simplistic ideas of 'relevance' to 'today's problems' — where fashions quickly change - as the appropriate standard for humanities teaching and research. Our proper 'mission is to describe, evaluate, imagine, and reimagine the human experience', through which, as the Harvard English medievalist James Simpson says, we continually 'recover', more than 'discover', knowledge, by going back to the 'deep archive'.

A different approach to 'relevance' might be to argue that applying it as a standard of value in university studies may foster anti-intellectual and antieducational tendencies. Reifications of relevance offer shelter to lazy-mindedness, and encouragement to complacency in ignorance. Like racial and religious prejudice, about which medievalists know a great deal, the belief that one knows in advance what is and is not 'relevant' forecloses curiosity, protects one's favourite assumptions from potential critique, and resists new thinking. When declarations are handed down about the 'relevant' 'big problems' of 'today', diversity is discouraged, because everything else is implicitly off-track, minor or archaic.

Objections apply also to the assumptions behind such uses of the term 'today', which imagine a present moment in which humans all live together on equal terms and of one mind, in a fluent course of history that continually makes the past 'out of date'. In the ultimate logic of this mindset, which no person or group possesses in actual experience, 'today' is a discrete and uniform read-out of current data, without a memory, blind to the diverse, multi-layered and entangled

6 The Sword in the Stone, dir. by Wolfgang Reitherman (Disney Enterprises, 1963).

7 Ireland, 'Mapping the Future'. 
nature of human culture and society, and ignoring the historical factors that have shaped and potentiated ideas of what the present day is.

The research of medievalists is well placed to intervene here, with its stronger grasp of 'temporalities'. In recent publications the medieval cultural historian, Matthew S. Champion, writes:

Temporalities are to time what materialities are to matter: a blurring of what might seem determined, an entangling of time with action, a refusal of subject-object divisions. [....] Temporalities are always bound up, too, with the scholar's own temporal settings. The history of temporalities is, in this mode, a self-reflexive history that must be alert to the temporal forms of historical analysis and representation, and to temporal assumptions and habits that shape fields and objects of knowledge. ${ }^{8}$

Champion advocates "the possibilities of a historical practice which is "full": which does not position the past as an inactive, dead, foreign country, but allows voices from different times and places to speak in a temporally variegated present' .

I welcome this outlook, and would argue that there is a strong social benefit in respecting cultural and intellectual biodiversity from the past, as there is in respecting cultural variety within our communities, and biodiversity in the natural environment, to protect it from selfish needs of 'today'. We need to keep listening out for voices from the past, as we need to listen out for the voices of people that current regimes of power prefer to keep silenced. As in anthropology, there is a self-reflexive function in this activity, because past voices can only 'say' what the nature of our conversation with them permits: in medieval studies, as in other areas, there are languages to be learned, cultural differences to be understood, contexts of utterance and reception to be considered, before we can know what matters most to us. The educational process involved allows a vast extension of human knowledge, intellectual development, and pleasure that carries much of its own justification.

There is also a necessary evaluative function: what we know of the medieval past, for instance, is often enough unpleasant, and it has been regularly found apt for bad uses ever since, including today. Forms of white supremacism, whether based in religion, accepted as 'scientific' fact, randomly opportunistic, or simply taken for granted, have always featured within the reception of the Middle Ages. Evocations of the 'Knights Templar' to lend prestige to the perpetrators of violent atrocities stemming from racial and religious hatred are one current example. Medievalists worried by appropriations of their subject for racist ends are rightly concerned to decolonize the field of medieval studies, extend its focus beyond

8 Matthew S. Champion, 'The History of Temporalities: An Introduction', Past \& Present, 243 (May 2019), 247-54 (p. 247).

9 Matthew S. Champion, 'A Fuller History of Temporalities', Past \& Present, 243 (May 2019), 255-66 (p. 266). 
Europe, and attend to other than white voices from the past. ${ }^{10}$ While we cannot erase the evils of prejudice apparent in the record of the Middle Ages, we can weaken and attack the practices of reception that ignore, falsify or sustain them, and so resist their symbolic transference into modern contexts. We can also, I hope, intervene usefully here because we know the specific differences between the medieval and modern bases of racism, and therefore can show how tenuous the 'medieval' connections of modern racists usually are. In this context, our knowledge can help by resisting attempts to make the medieval record satisfy a narrow desire for present relevance.

10 Initiatives of this kind have occurred more generally in literary and historical studies for some time. See for example, Global Chaucers: Online Archive and Community for Post1945, Non-Anglophone Chauceriana, <https://globalchaucers.wordpress.com/tag/candacebarrington/>; National History Center, 'Teaching Decolonization Resource Collection' $<$ https:// nationalhistorycenter.org/teaching-decolonization-resource-collection/?fbclid=IwAR21uiHdp5 h7ALphxXtSmUgbCeWCV5-pOtmsPstXpsQh2uCvsXBHe-DIZcM>; European Cooperation in Science \& Technology, 'People in Motion: Entangled Histories of Displacement across the Mediterranean (1492-1923)' <https://e-services.cost.eu/files/domain_files/CA/Action CA18140/mou/CA18140-e.pdf>. 